\title{
IMAGENS FOTOGRÁFICAS NAS PRÁTICAS PEDAGÓGICAS: \\ compartilhando saberes no Ensino Superior
}

\author{
Mario Roberto Venerel \\ Melissa Velanga Moreira ${ }^{2}$ \\ Carmen Tereza Velanga ${ }^{3}$
}

\begin{abstract}
RESUMO
Este artigo tem como objetivo averiguar as contribuições e as experiências obtidas por professores e acadêmicos da educação superior dos cursos da Universidade Federal de Rondônia - UNIR com o uso de imagens fotográficas como instrumento didático-pedagógico na sua formação, além de suas contribuições como ferramenta metodológica na aula universitária. Trata-se de pesquisa de abordagem qualitativa, de cunho etnográfico, cujos instrumentos foram: a observação da prática docente e a entrevista com professores e acadêmicos, pertencentes aos cursos de Pedagogia, Ciências Sociais, Letras, Medicina, Enfermagem, Biologia, Matemática e Geografia da UNIR, durante um estudo ao longo de quatro semestres letivos, concluída no segundo semestre de 2018. Os resultados mostram que os docentes, em sua maioria, utilizam as imagens fotográficas como recurso didático, sendo que estas possibilitam aos professores reflexão das atividades em sala de aula, contribuindo na formação dos seus alunos. A utilização da imagem fotográfica contribui para o processo de ensino e aprendizagem na formação superior, auxílio para a prática pedagógica reflexiva.
\end{abstract}

Palavras-chave: Ensino Superior. Imagem fotográfica. Prática Pedagógica.

\footnotetext{
1 Doutor em Educação Escolar (Faculdade de Ciências e Letras de Araraquara/FCLAR/UNESP/Brasil). Professor na Universidade Federal de Rondônia-UNIR, Núcleo de Saúde-NUSAU, Campus de Porto Velho-RO, Brasil. Membro do Grupo de Estudos do Desenvolvimento e da Cultura Corporal, e do Grupo de Estudos e Pesquisas Práxis/UNIR. Orcid iD: https://orcid.org/0000-0002-9691-9497. E-mail: mrvenere@hotmail.com

${ }_{2}$ Mestre em Letras (Universidade Federal de Rondônia). Professora de Língua Portuguesa e Literatura Brasileira do Instituto Federal de Ciência e Tecnologia de Rondônia (IFRO), Campus de Colorado do Oeste/RO, Brasil. Membro do Grupo de Pesquisa Linguagens, Artes e Humanidades em Educação na Contemporaneidade/ IFRO/RO. Orcid iD: https://orcid.org/0000-0001-6269-363X. E-mail: melissavelangamoreira@gmail.com

3 Pós-Doutorado em Educação (FEI/Universidade de São Paulo/USP, Brasil). Professora Titular aposentada do Departamento de Ciências da Educação da Universidade Federal de Rondônia (UNIR). Membro do Grupo de Estudos e Pesquisas EDUCA/UNIR; Práxis/UNIR e do Grupo de Estudos Interdisciplinares das Fronteiras Amazônicas/GEIFA. Orcid iD: https://orcid.org/0000-0002-1324-4704. E-mail: carmenvelanga@gmail.com
} 
PHOTOGRAPHIC IMAGES IN PEDAGOGICAL PRACTICES: sharing knowledge in Higher Education

\begin{abstract}
This article aims to investigate the contributions and experiences obtained by teachers and academics of higher education in the courses of the Federal University of Rondonia-UNIR- with the use of photographic images as a didactic-pedagogical tool in their training and their contributions as a methodological tool in Class University. This is a research with a qualitative approach, of an ethnographic nature, whose instruments were: the observation of teaching practice and the interview with teachers and academics, belonging to the Pedagogy, Social Sciences, Literature, Medicine, Nursing, Biology, Mathematics and Geography courses from UNIR during a study over four academic semesters, completed in the second semester of 2018. The results show that the majority of teachers use photographic images as a didactic resource, which enable teachers to reflect on activities in the classroom, contributing to the training of their students. The use of photographic image contributes to the teaching and learning process in higher education, and aid to reflective pedagogical practice.
\end{abstract}

Keywords: Higher Education. Photographic image. Pedagical Practice.

\title{
IMAGENES FOTOGRAFICAS EN PRACTICAS PEDAGOGICAS: compartir conocimientos en Educacion Superior
}

\section{RESUMEN}

Este artículo tiene como objetivo investigar las aportaciones obtenidas por docentes y academicos de educacion superior en los cursos de la Universidad Federal de Rondonia-UNIR- con el uso de imágenes fotograficas como herramienta didacticopedagogica en su formacion y sus aportaciones como herramienta metodologica en clase universitaria. Se trata de una investigacion con enfoque qualitativo, de carácter etnografico, cuyos instrumentos fueronÑ la observacion de la practica docente y la entrevista a docentes y academicos, pertenecientes a los cursos de Pedagogia, Ciencias Sociales, Literatura, Medicinaa, Enfermeria, Biologia, Matematica y Geografia de UNIR durante un estudio de cuatro semestres academicos, que se completo en el segundo semestre de 2018. Los rersultados muestran que la mayoria de los docentes utilizan imágenes fotograficas como recurso didactico, que les permite reflexionar sobre las actividades en aula, contribuyendo a la formacion de sus alumnos. El uso de la imagen fotografica contribuye al proceso de ensenanza y aprendizaje en la educacion superior, una ayuda para la práctica pedagogica reflexiva.

Palavras clave: Ensino Superior. Imagen Fotografica. Practica Pedagogica.

\section{INTRODUÇÃO}

Para traçar caminhos no intuito de averiguar como são operacionalizadas as práticas pedagógicas na formação dos diversos 
profissionais no Ensino Superior em um dos estados da Amazônia brasileira, valer-se da abordagem qualitativa para o trabalho de pesquisa foi nossa opção metodológica, assim como a técnica de entrevista para a coleta de dados, de acordo com a que está proposta por Andrade (2002, p. 85): "[...] entrevista despadronizada ou não estruturada, que consiste em uma conversação informal, que pode ser alimentada por perguntas abertas, proporcionando maior liberdade para o informante".

O estudo empírico ocorreu no transcorrer de quatro semestres letivos, sendo a pesquisa estruturada no segundo semestre de 2018 com docentes e discentes de alguns cursos de graduação da Universidade Federal de Rondônia (UNIR), do Campus de Porto Velho (RO), a saber: Pedagogia, Educação Física, Letras, Ciências Sociais, Geografia, Administração, Enfermagem, Biologia e Medicina, e ainda, alunos do Programa de PósGraduação em Desenvolvimento Regional, nível mestrado.

A pesquisa ocorreu a partir do envolvimento com as tecnologias que consideramos levar para nossas aulas, bem como em projetos articulados com 0 Laboratório Didático-Pedagógico Multimídia (LABMíDIA4). Desenvolvido em parceria com a Pró-Reitoria de Graduação (Prograd), ao longo de nossa docência, desde a participação através do Programa de Consolidação das Licenciaturas em 2008. Consta dessa época o envolvimento de dois dos docentes que apresentam este artigo, com a fotografia como instrumento didático.

Deste ato de apreciar o impacto causado pela imagem fotográfica e outras tecnologias nos cursos dos quais participamos como docentes, passamos a observar e a registrar tais percepções com colegas professores e alunos desses cursos, nos quais percebíamos o emprego da fotografia. Desejávamos investigar se a fotografia estaria sendo aplicada como recurso

${ }^{4}$ O Laboratório Didático-Pedagógico Multimídia (LABMIDIA) tem como objetivos: atender às necessidades de capacitação no uso da tecnologia Educacional, tanto nos projetos de extensão quanto nas licenciaturas, a fim de se transmitirem técnicas de ensino com o uso da multimídia; produzir materiais didático-pedagógicos e, multiplicar a informação técnicometodológica, contribuindo para a melhoria da qualidade do ensino, através da transformação dos seus meios tradicionais em multimídia, a fim de facilitar, não só a aquisição de conhecimento, mas a sua difusão de forma prática e eficiente junto aos cursos de graduação/pós-graduação da Universidade Federal de Rondônia (UNIR, 2007).

Revista Exitus, Santarém/PA, Vol. 11, p. 01 - 25, e020135, 2021. 
didático na aula universitária e quais procedimentos estavam sendo adotados pelos professores que conseguiam tal feito, assim como os efeitos sobre a prática pedagógica.

\section{O ATO DE FOTOGRAFAR}

Entendemos que fazemos parte da geração responsável pela ampliação do domínio de tecnologias criativas que venham a auxiliar nos diversos ramos do conhecimento humano e, no que concerne à academia, tal domínio, com qualidade, é capaz de mudar paradigmas das atividades científicas e artísticas na formação do sujeito e do profissional, que busca na Universidade esta formação mais complexa.

Buscando compreender melhor os suportes didáticos atuais, inclui-se a fotografia mais do que simples instrumento de apoio, mas algo que merece atenção e leitura conceitual à luz de várias ciências, das humanas e sociais às exatas e biológicas. Essa abordagem merece tratamento interdisciplinar e transdisciplinar, de tão complexa que pode ser sua compreensão e abrangência, pois libera a criatividade dos que com ela lidam, bem como possibilita insights verdadeiros para o processo de ensino e aprendizagem. Está presente no cotidiano, nos diversos meios de comunicação, e hoje, nas formas estáticas e dinâmicas em seu uso, levando encantamento, fascínio e proporcionando reflexões para os que nela se debruçam. Isto ocorre em qualquer lugar do mundo, do ocidente ao oriente, em dimensões diferentes, sob olhares diferenciados, em realidades particulares, mas sempre de forma universal, no que diz respeito a formas, níveis e processos de aprendizagem pela imagem.

Concordamos com Carlos (2002), quando afirma que no campo educacional há uma tomada de consciência quanto a sua utilidade na comunicação, assim como ajuda a formação de conceitos em várias disciplinas do currículo, constituindo-se uma alternativa didática e de superação ao paradigma linguístico, representado pelo texto escrito, como central e hegemônico no desenvolvimento da sociabilidade humana. 
Não é nossa intenção aqui descrever a fotografia enquanto técnica, tampouco nos referir ao processo histórico, aos precursores da fotografia, ao seu desenvolvimento e as suas ramificações, como o primeiro filme de rolo, o cinema, a televisão, as artes gráficas, as imagens usadas na área médica (ecografia, fotomicroscopia, radiografia, endoscopia, etc.), os espectros não visíveis, registros e documentos aeroespaciais, computação gráfica, fotografia digital, dentre outras. Uma infinidade de usos e de campos onde se aplica a fotografia como recurso de ampliação da informação, de criação de ideias, hipóteses, pois isso fugiria do nosso objetivo para este estudo que somente tentará pontuar, nesse universo em expansão constante, a fotografia como recurso didático no ensino superior. E, como princípio, para além de uma técnica, a trazemos como arte.

Para Mansur (2005, p. 2) "fotografar é eternizar os momentos para que as próximas gerações possam sentir, olhar e aprender com eles o que hoje estamos construindo". O autor cita Francastel (1993 apud MANSUR, 2005), quando afirma que a arte tem como matéria-prima o real, mas sempre the acrescenta algo:

[...] A arte registra tudo que há de irracional e de passional daqueles que a criam, dos que a desejam, e os que a usam. Manifesta o mito, mas cria a utopia. O ato de fotografar é uma arte quando retrata o corpo, paisagens, movimentos sociais, momentos históricos, cenas do dia a dia, a vida religiosa, cultural, social, política e econômica. 0 profissional revela sua alma, desejos e ideologia através de seus olhos, dedos e pensamentos. E quando o fotógrafo revela sua alma por meio das imagens e estas se tornam fragmentos da vida; não podem simplesmente ser usadas para ilustrar ou adornar um artigo, coluna, capa de livro ou jornal (MANSUR, 2005, p. 2).

Entende-se que a fotografia, como técnica e arte é, antes de tudo, uma "revelação", um ato de mostrar-se e demonstrar ao outro o que quer que queiramos que se veja, embora este último objetivo não esteja, necessariamente, ligado ao primeiro, ao de revelar, pois cabe aqui a subjetividade, o olhar de quem vê o que foi capturado pelo outro. Nesta complexa relação, o ato de fotografar é algo que demanda arte e técnica. 
Em referência ao trabalho didático com a fotografia, convém ressaltar que além de instigar o ato de fotografar como curiosidade artística, é importante que professores e alunos trabalhem as questões básicas, isto é, a linguagem fotográfica, as técnicas mais apropriadas para captar as imagens, apurar a sensibilidade no olhar sobre o objeto e buscar uso didático do processo e do produto final, a fotografia propriamente dita. Proporcionar momentos de deleite em primeiro lugar, para, com a técnica, introduzir o aluno no seu uso didático, certamente é uma contribuição e uma estratégia a ser lançada pelo professor junto ao seu aluno, tendo por finalidade o seu envolvimento com os estudos de forma qualitativa e prazerosa.

\section{IMPORTÂNCIA DA FOTOGRAFIA COMO RECURSO DIDÁTICO NO ENSINO SUPERIOR}

Um dos autores tem aprendido fotografia para além de um hobby, resolvendo empregá-la como ferramenta didática no curso onde atua como docente, e como membro atuante no LABMIDIA. Como apaixonados pela arte e pela possibilidade pedagógica, pensamos em criar uma oficina de fotografia, cujo objetivo principal foi o de instrumentalizar universitários para a captura, armazenamento, análise e manipulação de imagens. Com este ponto mais geral no horizonte, determinamos os objetivos específicos: a) disseminar no ambiente acadêmico da Universidade Federal de Rondônia (UNIR) o conhecimento de técnicas fotográficas; b) promover a informação profissional sobre a utilização adequada da imagem adquirida através de equipamentos de fotografia; c) contribuir para a melhor exposição de trabalhos acadêmicos no que diz respeito à utilização de imagens; d) fomentar a realização de eventos com a inclusão de gêneros fotográficos; e) aprimorar conhecimentos adquiridos sobre a dimensão estética de registros, criação e reproduções visuais. Com o foco nos objetivos, foi elaborado o Projeto do Curso de Fotografia, envolvendo professores e alunos dos diversos cursos da UNIR. Foram ministrados vários cursos de cerca de 30 horas com os recursos do LABMIDIA: máquinas fotográficas analógicas e 
digitais, filmes, computadores, tripés, paspateur, além do espaço físico interno do laboratório-sala-de-aula e de espaços outros, como os bosques da Universidade, ensejando aos cursistas a opção de fotografarem por puro prazer e deleite, uma estratégia de sensibilização utilizada no curso.

Primeiramente, consideramos importante discutir o tema com os participantes, principalmente para verificar que impacto a imagem poderia causar nesta comunidade, como forma de contribuir para a pesquisa gerada nas disciplinas ou projetos de seus cursos. Também consideramos importante que o professor organizador da atividade prática das oficinas fizesse todo o registro de como a mesma se desenvolveu, a fim de que, por sua vez, gerasse reflexões críticas direcionadas à prática pedagógica. Um dos elementos a serem analisados, por exemplo, foi a espontaneidade da criança no momento da realização do exercício em aula de Educação Física, instante onde o professor pode observar em que situação a criança realiza o movimento, e depois, como aprimorá-lo; ou seja, o próprio professor pode usar a imagem capturada para corrigir os próprios erros em sua orientação pedagógica junto aos alunos.

As imagens registradas e compartilhadas com os alunos, participantes ou não, vão gerar estímulos no planejamento de outras atividades. De fato, as exposições das imagens feitas pelos participantes do curso de fotografia, causaram estímulos e uma reflexão sobre a importância de registrar as imagens para no futuro serem geradoras de pesquisa.

Barros (2004, p. 6), em estudos sobre a utilização das fotografias para a inclusão, afirma que:

As fotografias podem servir-nos como fontes históricas iconográficas, possibilitando a pesquisa sobre sociedades, remetendo a tempos e lugares, informando figurativamente sobre vestuário, tipos étnicos, composição de gênero, arquitetura, materiais e recursos pedagógicos. A tradição historiográfica com o uso da fotografia, apesar de recente, informa-nos sobre possibilidades instigantes a serem exploradas, inclusive na formação de novos profissionais de ensino. 
Essa possibilidade da utilização da fotografia como recurso na pesquisa científica tem sido aumentada na apresentação de trabalhos científicos, especialmente na Universidade Federal de Rondônia na qual, além de participantes, temos sido observadores de trabalhos expostos e apresentados em encontros, congressos e demais eventos realizados, desde 2004, período que nos envolvemos com a pesquisa sobre a análise da fotografia como ferramenta didática, sendo demonstrados publicamente os resultados em imagens.

No que se refere à utilização da fotografia como recurso didático, Barros (2004, p. 6), afirma ainda que:

[...] é possível utilizá-las como "motivadoras", como "estratégia", permitindo a discussão de assuntos nas mais variadas disciplinas, possibilitando a abordagem de questões sociais amplas a partir da comparação entre a produção fotográfica privada, familiar e aquela produzida pelo Estado e pelas mídias. As imagens fotográficas podem servir a uma "educação do olhar"? Sim, na medida em que a sociedade é saturada por imagens na mídia e não dispõe de espaços que permitam a apreensão dos códigos que as constroem, a escola, entre outras atribuições, deve sistematizar conhecimentos voltados à historicização desse recurso. A fotografia pode igualmente apoiar a construção de conceitos, especialmente na dimensão espaço-temporal. Isto porque a fotografia é, simultaneamente, na dimensão do suporte papel, um "isto foi"/"isto aconteceu", permitindo uma discussão sobre o conceito de "tempo", de "agora", de "depois", de "passado", e adequa-se, também, à oportunidade de discussão espacial, uma vez que o suporte papel pode evidenciar (desde que a criança tenha participado na construção do registro fotográfico) o conceito de "isto aí", na oposição de "aqui/ali".

Neste contexto, desenvolver a sensibilidade para a captura da imagem é um dos pontos fundamentais para que o professor que deseja usar o recurso fotográfico na sua atividade docente tenha êxito em suas atividades. Para capturar essas imagens há necessidade de um olhar mais apurado capaz de transmitir e estimular o aluno a desenvolver tal sensibilidade. A imagem propicia a aprendizagem uma vez que, transformando-se em modelo, não apenas se torna a réplica do material original, como também propicia novos modelos e possibilita novas percepções. 
Apoiando-nos em Dondis (2007, p. 86), defendemos certamente a necessidade premente de que uma educação visual seja popularizada, pois "a reprodução da informação visual natural deve ser acessível a todos".

IMPACTOS DO USO DA FOTOGRAFIA NA RELAÇÃO PROFESSOR/ALUNO/CONTEÚDO DE ENSINO NOS CURSOS UNIVERSITÁRIOS DA UNIR: Relatos de Práticas

A pesquisa empírica ocorreu através da observação da prática docente e a inclusão do uso do recurso fotográfico nas atividades de professores da UNIR, em diversos cursos. Não tivemos a preocupação de delimitar os sujeitos e os cursos, pois partimos da premissa de que os professores que já usavam espontaneamente tal recurso, ou mesmo os estimulados pelos cursos de fotografia oferecidos no LABMIDIA, poderiam dar depoimentos de como a fotografia impactava suas práticas. Por sermos igualmente docentes, participamos também desses cursos como ministrantes ou cursistas, o que nos levou a escolher a abordagem qualitativa no registro e análise dos dados como a mais adequada à compreensão dessa realidade.

Buscamos registrar depoimentos e entrevistas com professores dos cursos de Pedagogia, Ciências Sociais, Letras, Medicina, Enfermagem, Biologia, Matemática e Geografia, durante os anos 2017 e 2018, anotando em cadernos de bordo as observações feitas acompanhando aulas de campo, e mesmo no espaço restrito da sala de aula. Percebia-se nestes momentos, que o uso do recurso da fotografia evidenciava as iniciativas dos docentes verdadeiramente envolvidos nas suas atividades, e um cuidado especial no planejamento das suas propostas. Percebeu-se que, ao estimular seus alunos para a captura da imagem, criou-se um recurso para se fazer uma reflexão da atividade realizada em sala de aula. E, por ser imagem real, de uma realidade vivida, causa-se mais impacto na aprendizagem do que, em muitos casos, simplesmente a discussão em torno de um texto escrito, pois os efeitos das imagens possibilitam ao professor e aluno efetuarem reflexões acerca do assunto, levando a interações rápidas e respostas mais 
reflexivas, contribuindo assim para a formação responsiva que o professor pretende desenvolver junto aos alunos. Como afirmou uma professora do Curso de Letras: "É importante verbalizar o que as fotos nos falam, é preciso também saber ouvi-las, saber VER o que está dizendo, perceber e sentir" (informação verbal).

Na mesma percepção da importância do aprimoramento do "olhar e sentir", afirmou um professor ministrante da disciplina Legislação Educacional no curso de Educação Física:

A imagem é importante na formação do educando pela possibilidade de efetuar leituras das próprias imagens. Utilizando a técnica VOS, em que a gente Vê, Ouve e Sente. O professor divide a turma em três grupos e disponibiliza as imagens fotográficas para que os mesmos efetuem análises de cada uma, discute sobre aquelas imagens, procurando VER os detalhes; OUVIR... e SENTIR (informação verbal ${ }^{5}$ ).

No excerto de fala anterior, percebe-se a forma sensível do trabalho do professor junto aos seus alunos. Observamos que as atividades ministradas que utilizam a fotografia como recurso, ou até mesmo método, em muito contribui na operacionalização de suas aulas, descrevendo que houve maior interesse dos mesmos em discutirem determinados assuntos que são perceptíveis nas imagens fotográficas.

Outra experiência vivenciada por nós em exposições e palestras realizadas em cursos na UNIR, dentre eles o curso de licenciatura em Ciências Sociais, deu-se pela abertura de espaço para um debate entre os acadêmicos, que efetuaram análises de imagens fotográficas, utilizando a metodologia de análise e discussão sobre as diversas fotos ali presentes. Naquele momento, efetuou-se a "Mostra Fotográfica" de autoria de um dos professores pesquisadores deste artigo, "Paulo Freire e o Encontro com a Exclusão Social", na qual continham os registros fotográficos sobre populações do nordeste brasileiro, enfocando a realidade social em que vivem aquelas pessoas. No decorrer da discussão houve o estabelecimento

\footnotetext{
${ }^{5}$ Comentário de um professor do Departamento de Ciências da Educação durante uma disciplina ministrada no curso de Educação Física.
} 
de um diálogo do expositor com os acadêmicos, que falaram do seu envolvimento com aquela situação, possibilitando-Ihes sentir situações expressas nas imagens, muitas delas conhecidas, outras, completamente desconhecidas, possibilitando um amplo debate. Outra experiência se deu no Curso de Educação Física, onde este professor trabalhou as imagens de diversas crianças realizando atividades do atletismo. Naquele momento, os acadêmicos tiveram a oportunidade de "ver" e "sentir". A partir daí foram formados grupos em que cada um recebeu uma fotografia para efetuar a análise e a descrição. Em sequência, os acadêmicos procederam à análise, descreveram a temática trabalhada para, posteriormente, exporem suas percepções sobre o assunto.

Diante da observação de como os alunos agiam frente à imagem, aventando hipóteses do que estava ocorrendo, percebemos que a imagem fotográfica possibilita ao futuro profissional de Educação Física observar, além dos movimentos clássicos das modalidades, o espaço em que é realizada, bem como a realidade que eles encontrarão quando forem prestar serviços naqueles estabelecimentos de ensino, ou em visualizarem como é operacionalizada a modalidade, propiciando a fixação dos conteúdos relacionados ao atletismo.

Observamos que na prática docente dos alunos universitários, em virtude da escassez de recursos tecnológicos das escolas públicas onde fazem seus estágios, o aluno prepara suas aulas esperando encontrar à sua disponibilidade equipamentos específicos, como: data show, computador ou outros materiais auxiliares, mas dificilmente isso ocorre, assim, os professores são obrigados a lançar mão de imagens sobre os esportes, disponibilizadas na Internet ou em livros e periódicos, que possibilitam visualizá-las e são direcionadas aos conteúdos abordados em sala. Em conversa com uma aluna do curso de Educação Física, que é também professora da rede pública de ensino, esta relatou que "[...] ao ministrar aulas para alunos adultos percebi a necessidade de criar novas metodologias para incentivar suas participações nas aulas de Educação Física". A partir daí ela procurou na Internet imagens de cenas relativas à "História dos 
Esportes e da Educação Física". As imagens foram expostas em sala de aula e, após o término do encontro, os alunos solicitaram para que fosse trabalhado novamente, mostrando aquelas imagens, nas aulas posteriores sobre o assunto.

Registramos também o depoimento de uma aluna do curso de Pedagogia, que descreve o seu conceito sobre a importância da fotografia como recurso didático da seguinte maneira: "Para mim ela é uma forma de passar uma mensagem, ela fala muito mais forte que a escrita. Ela consegue dar aquele impacto, mas muitas vezes a leitura não dá" (informação verbal).

Percebeu-se, na fala da estudante, a necessidade de se discutir a utilização da imagem fotográfica nos cursos de formação de professores, pois a mesma possibilita a criação de metodologias para ministrar aulas nos diversos níveis de ensino.

Também é reforçada a importância da utilização da fotografia por uma professora do Curso de Letras. Ela relata que a fotografia é: "Um dos recursos do mundo moderno que pode auxiliar no exercício da docência a compreender o mundo, o homem e a sociedade. Nunca trabalhei com fotografias, gosto de trabalhar com litografia e fitas de vídeo" (informação verbal).

Uma Professora do Curso de Letras da UNIR também contribuiu com o seu posicionamento para refletirmos sobre a importância da fotografia na sala de aula universitária, enaltecendo a utilização deste recurso didático:

A Fotografia como recurso didático pedagógico vai ampliar a concepção do aluno em relação aquilo que vai ser mostrado, lugar, parte do corpo, etc. Nós trabalhamos muito abstratamente, a fotografia não vai contribuir só no concreto, a fotografia é uma representação daquilo, ela proporciona ao aluno uma ampliação de seus conceitos. A fotografia não é um objeto em si, ela tem uma subjetividade do fotógrafo. Essa subjetividade vai fazer o contato com o outro, vai produzir outro sentido (ângulo, iluminação, enquadramento...), vai construir para produzir sentido com os outros. A fotografia é um texto não verbal. $\mathrm{Na}$ análise do discurso a fotografia é um enunciado, a função deles é que vai produzir outros ganhos que o fotógrafo objetiva só que ele não é o dono dos sentidos (informação verbal). 
Acentuadamente temos perdido oportunidades de efetuarmos registros significativos por não conhecermos os procedimentos básicos da linguagem fotográfica, isto é, o enquadramento, planos, profundidade de campo, luz, dentre outros, conceitos estes de fundamental importância para se fazer fotografias. Essa falta de preparação é percebida na fala a seguir, em que a profissional de Fisioterapia relata: "Eu perdi de acompanhar tratamento de meus pacientes, por não saber tirar fotografias" (informação verbal).

O que é enfatizado também pelo professor de Educação Física, no depoimento a seguir:

Você mostra a imagem, a criança fazendo o exercício, o aluno olha - aparelho, a movimentação da criança. Ele mesmo vendo a imagem para imaginar o que a criança faz. Você não consegue escrito. Principalmente se está em outra área. Por exemplo: quando você sai do tradicional, em que vai utilizar o apoio, a flexão de braços, para um estudo através da imagem de como funciona o coração. Você vê a imagem e vai mostrando[...] a imagem transmite muito mais interesse do que a escrita, mais atenção, mais curiosidade e talvez até melhor aprendizagem.

Este último excerto nos propicia observar que além da utilização da imagem para a demonstração do exercício, é importante o uso das novas tecnologias na captura e exposição dos conteúdos. Nesse sentido, no caso de uma disciplina de Fisiologia, na qual o professor tem que demonstrar aos alunos o funcionamento interno de uma determinada situação, possibilita mais sua compreensão do órgão em estudo.

Contribuindo com este pensamento, o professor de Anatomia no curso de Medicina da UNIR assim define a importância da fotografia:

A fotografia particularmente em anatomia, o uso é importante porque é o que a gente mais utiliza. Tenho trabalhado com imagens de Atlas, PowerPoint, radiologia, tudo é efetuado através da imagem. Hoje em dia existem os softwares com imagens animadas do corpo humano. Em termo da disciplina tem tudo a ver, pois, sem o recurso visual não tem como ministrar aulas, é importante tanto no imagético como no concreto (informação verbal). 
A aplicabilidade da utilização dos recursos visuais torna-se fundamental na realização das aulas, opção reafirmada por outro professor da disciplina Anatomia nos cursos de Educação Física e Medicina da UNIR, enfatizando que:

\begin{abstract}
Durante as aulas de anatomia é fundamental a utilização das imagens, não tem jeito de ministrar aulas sem a projeção de imagens. No meu tempo de estudante, os professores ministravam aulas com slides. Eu tinha que fotografar e passar para os slides. Hoje, minhas aulas são riquíssimas em imagens e, quando solicito aos alunos para ministrarem aulas, é um espetáculo, esses recursos disponibilizados pelas novas tecnologias é um espetáculo (informação verbal).
\end{abstract}

Na visão de um professor de Filosofia, as imagens "[...] têm um caráter simbólico muito forte, ultrapassando, portanto, a mera imagem estampada. Tocando e movendo nossos arquétipos". Em diálogo com uma professora do Departamento de Filosofia e Sociologia da UNIR, socióloga, percebe-se também a importância dada à imagem na Educação Superior:

No mundo de hoje quem não se apropria da imagem como recurso de comunicação está perdido. A leitura do nosso mundo tornou-se muito visual. Para você conhecer o cotidiano, o concreto, o caminho tem sido a imagem; o acesso ao concreto passa hoje pelo virtual, é aquilo que em sociologia se chama 'second life'. A imagem tem uma força, um apelo muito forte, vem substituindo, na comunicação, com maior eficiência as palavras. Penso ser muito importante, usar as imagens nas ciências sociais, eu acho fundamental (informação verbal).

Como relata a nossa informante, entendemos que a utilização da imagem em sala é bastante válida, pois percebemos em nosso dia a dia, quando a utilizamos, que a mesma contribui para a apreensão do conhecimento, tornando-a um recurso metodológico significativo para a aprendizagem dos alunos.

Outra situação que nos permitiu constatar o uso da fotografia como recurso didático foi durante nossa incursão às salas de aula em caráter de observação e participação, quando estivemos presentes no momento da avaliação, ao término da disciplina de Didática Geral de um curso de 
Especialização. A professora desta disciplina utilizou recursos de fotografias da realidade escolar, pesquisadas e trazidas pelos alunos-professores da rede pública municipal de ensino, transpostas para o aplicativo Microsoft Office PowerPoint $\AA$, a fim de que seus alunos lessem a realidade apresentada e as analisassem à luz de teóricos da área. A atividade mostrou-se bastante produtiva e prazerosa, atingindo plenamente os objetivos didáticos propostos pela professora, segundo seu depoimento.

A seguir, transcrevemos as expressões de alguns alunos que se disponibilizaram a avaliar esta atividade:

Registrar as atividades desenvolvidas é procurar refletir sobre a prática buscando novos meios de melhorar, enriquecer, é manter na história feitos que são magníficos. Para a prática de ensino é oportunizar ao educando o acesso à reflexão e a um olhar sobre a sua própria aprendizagem (Grupo 4) - (informação verbal).

A utilização da foto subsidia um olhar para a criação e como recurso didático que alivia a teoria condensada, o uso da foto nos motiva a sonhar a respirar fundo e traz a doce sensação de saudade (Grupo 3) - (informação verbal).

Por ser um registro visual, a fotografia permite a demonstração de realidades seja para conhecimento, admiração, constatação e reflexão, ou para reconhecer, avaliar, comparar, analisar... de um modo mais significativo e que atende a uma grande parcela de pessoas/alunos que 'são' extremamente visuais e precisam de estímulos como os que as fotografias oportunizam (Grupo 2) (informação verbal).

Acredito que a importância está principalmente no desenvolvimento da afetividade entre professor e aluno e na motivação para a realização dos trabalhos escolares. Porque palavras se perdem no ar, mas o registro fotográfico lembra acontecimentos, que tornam 0 professor capaz de melhorar sua prática e o aluno lembrar bons momentos vividos na escola (Grupo 5) - (informação verbal).

Observou-se ainda a fala de uma técnica atuante na Educação a Distância/UNIR, que compartilhou conosco sua vivência em relação à utilização da fotografia no processo de aprendizagem dos alunos:

A fotografia é importante, principalmente na construção do conhecimento. Hoje, a Educação como Ciência na escola, a criança discute sobre o assunto em sala de aula e daí ela tem a oportunidade de ir a campo e capturar as imagens, que retratam aquela realidade e produz o seu conhecimento. Ela vai ver a 
imagem e, além disso, vai ter o próprio contato com o assunto. São duas produções de formas diferentes. Ela vai ter a imagem e, também, vai inseri-la no texto. Você ensina produzir e não a reproduzir (informação verbal).

Analisando o relato anterior, percebemos como a ministrante valoriza a utilização da imagem como recurso didático, sendo ela um dos pontos fortes de sua prática docente, possibilitando o envolvimento do aluno com o cotidiano.

Registramos também a fala de uma professora do campus de Guajará-Mirim, em que ela busca justificar o uso da imagem para representar a cena da realidade da empresa e o cotidiano das pessoas no ambiente de trabalho: "[...] a fotografia é melhor para os alunos memorizarem os conceitos, a prática, principalmente quando não temos acesso à empresa que o aluno deveria conhecer". Com a utilização desse "recurso tecnológico" possibilita-lhes mais tempo para "[...] trabalhar mais a informação em sala de aula". A professora utiliza a imagem para propiciar aos seus alunos vivenciarem o cotidiano de uma empresa, situação relevante, uma vez que são poucas as possibilidades que seus alunos têm de sair de suas localidades, pela dificuldade de acesso, como é o caso de muitas cidades do interior.

Na sequência, observa-se que o registro fotográfico possibilita aos alunos acompanharem o desenvolvimento de uma situação, como a descrita por uma professora do curso de Enfermagem, no tocante a utilização da imagem como recurso metodológico e didático:

Utilizo a foto-documentação, eu estudo a situação e vejo como é que eu vou trabalhar, tenho a cobertura de vários profissionais: o psicólogo que trabalha (sic) comigo. Efetuo registro da ferida do paciente e através da imagem eu vou observando 0 seu desenvolvimento. Tem seus registros que são efetuados diariamente, dependendo da gravidade do ferimento, outros são acompanhados quinzenalmente. As feridas crônicas eu acompanho duas vezes por semana, efetuo o registro. Tem umas feridas que são efetuados registros de quinze em quinze dias. Têm outras que eu registro duas vezes. Registrei a ferida de uma paciente e percebi que ela tinha tido uma melhora nos seus ferimentos. [...] naquela região houve ganho, verificou-se que a carne cresceu, isto eu pude observar através da imagem (informação verbal). 
A importância da utilização da imagem fotográfica no caso de um paciente acometido por algum tipo de doença é a de que não haverá necessidade de estar, por exemplo, quarenta alunos dentro de um pequeno espaço, situação que poderia prejudicar o próprio paciente. Portanto, fotografar a enfermidade, processar a imagem para ser projetada com recursos tecnológicos, contribuirá para poupar a saúde do paciente. Cabe destacar que, quando da utilização das imagens as quais estão envolvidos registros de seres humanos, é necessário solicitar autorização dos mesmos. Muitas vezes, o pesquisador não tem o consentimento dos fotografados e utiliza suas imagens, sem respeitar os direitos autorais, conforme o prescrito em leib. Tal desconhecimento em suas publicações pode levar a sanções prescritas em lei, assim como o ato de não respeitar os direitos autorais que determina as regras com relação aos registros de imagens.

Contribuindo com a sua experiência, um professor, geógrafo e fotógrafo amador, descreve porque optou por utilizar as imagens em suas aulas no Curso de Geografia:

[...] a fotografia é um recurso que a gente tem, além de ser um documento, ela ajuda a gente fazer a discussão de uma forma muito mais completa, porque você pode contar com a imagem. Então você pode ser o autor da foto que fica muito mais interessante, ou você pode usar outras fotos, fotos de outras pessoas dentro do tema que você está explorando. Se quiser colocar, eu como geólogo, uso desde quando comecei escrever trabalhos. Agora que você pode usar fotos digitais é uma coisa que agora a gente pode brincar muito mais. Eu fui fazer uma pesquisa em Corumbiara, um município aqui no estado de Rondônia, eu fiz umas duas mil imagens. Agora ela passa a ser um recurso fundamental em que você pode colocar texto, editar. Trabalhamos as fotografias em escalas mesoscópica e microscópica (informação verbal).

\footnotetext{
${ }^{6}$ A Lei n 9.610, de 19 de fevereiro de 1998, dispõe sobre o Direito Autoral em todas as áreas, inclusive a fotografia. A fotografia é considerada obra intelectual, e como tal está protegida pelo art. $7^{\circ}$, inc. VII. Art. $7^{\circ}$ : São obras intelectuais protegidas as criações do espírito, expressas por qualquer meio ou fixadas em qualquer suporte, tangível ou intangível, conhecido ou que se invente no futuro, tais como: VII - As obras fotográficas e as produzidas por qualquer processo análogo ao da fotografia.

Ver ainda:

Resolução $n^{\circ}$ 466, DE 12 DE DEZEMBRO DE 2012.

(https://bvsms.saude.gov.br/bvs/saudelegis/cns/2013/res0466_12_12_2012.html);

Resolução n 510, DE 07 DE ABRIL DE 2016.

(http://conselho.saude.gov.br/resolucoes/2016/Reso510.pdf).
}

Revista Exitus, Santarém/PA, Vol. 11, p. 01 - 25, e020135, 2021. 
Percebe-se que o Professor pode utilizar imagens já existentes e também fazê-las para a utilização em suas aulas. Na questão da fidedignidade da produção da imagem, é importante observar alguns aspectos: as pessoas têm que ficar atentas para saber como as imagens foram construídas? Qual a finalidade do autor em fazer aquelas fotografias? O que realmente ele queria mostrar? São campos ideológicos a serem observados?

O professor do curso de Geografia e do Mestrado em Desenvolvimento Regional da UNIR também enaltece a importância da fotografia como ferramenta metodológica nas aulas na Educação Superior:

\begin{abstract}
Quando a gente usa recurso audiovisual, muda a aula, a aula muda. A gente fala tanto, mas com foto é outra história, é outra história. Eu coloco no computador, passo no data show e a aula fica ilustrativa, beleza. Eu senti na prática a fotografia ela proporciona que, quem está aprendendo, aprenda aquilo que ele quer e não o que o professor quer que ele aprenda para você ensinar para o outro. Se ele autoensina, ele produz e, o professor tem importância fundamental, mas tem que ensinar o autoaprender aos alunos, a bagagem de aprender, isso a fotografia proporciona. Isso na prática a gente utiliza e quando acerta a aula é outra coisa, outra história outro nível (informação verbal).
\end{abstract}

Concordamos com Silva et al. (2017, p. 3), no estudo que discute a fotografia como recurso mediático no Curso de Geografia:

No cotidiano da sala de aula, o processo de comunicação proveniente da utilização das imagens fotográficas como material de apoio didático, pode viabilizar uma prática educacional mais direcionada à formação de cidadãos críticos. Desde que, na linguagem da Comunicação Visual o conceito de Educar transmude para Ensinar a olhar. Num mundo onde vivemos rodeados de imagens, o fundamental é saber interpretá-las, de modo que, ao observar uma imagem, o indivíduo seja capaz de desvendar seus vários sentidos e correlacioná-los com os aspectos geográficos.

Um professor do curso de Ciências Biológicas também utiliza as imagens fotográficas em seus trabalhos de pesquisa e observa a importância da utilização, principalmente das imagens fotográficas digitais, que no 
cotidiano vem auxiliando pesquisadores a solucionar problemas em determinadas situações de pesquisa:

Muitas vezes ao coletar uma espécie de planta e enviá-la pelos correios, você pode acabar perdendo-a, há muita burocracia, antes era muito burocrático. Uma espécie não determinada você faz a fotografia com uma resolução razoável, que possibilite a visualizar as estruturas, você envia para os especialistas em qualquer parte do mundo via e-mail e, em poucos dias você tem a resposta. Muitos pesquisadores procedem desta maneira, evitando custos e também o desvio do material (informação verbal).

Por exemplo, é importante que o pesquisador conheça como utilizar os seus equipamentos, tenha conhecimentos básicos sobre como fazer as fotografias, conhecer os recursos tecnológicos para a captura das imagens e, a partir daí, saber qual quantidade de luz utilizar, se há necessidade do uso do flash ou não, ou de dar tempo suficiente de exposição. Caso necessite utilizar a luz natural ou artificial, quais seriam seus procedimentos. 0 foco, para que se tenha uma boa profundidade de campo, bem como o enquadramento. São observações importantes, pois quem vai analisá-las tem que ter todas as especificações preservadas na imagem a ser identificada.

Outro exemplo a ser observado é quando são feitas fotografias de fósseis, utilizadas pelos paleontólogos, pelos geólogos que utilizam uma referência padrão, para que possam comparar o tamanho daquela espécie. Um professor Paleontólogo do curso de Ciências Biológicas, em depoimento dado nos orientou que, para melhor referenciar o objeto fotografado, o pesquisador tem que se utilizar de uma medida padrão, tal como uma régua, pintá-la e fazer uns quadrinhos em preto e branco, por exemplo, com um tamanho de aproximadamente dois centímetros cada. Aconselha ainda aos "[...] pesquisadores que fazem fotografias de insetos que utilizem papéis milimetrados comuns e, as células especificadas em milímetros".

Nesta perspectiva, devemos atentar para as observações de outro professor e pesquisador do curso de Ciências Biológicas, alertando para a 
necessidade de "[...] ao fotografarem insetos, é importante que se atente para a questão da constituição física do animal e também para que as resoluções de captura das imagens sejam boas". Assim, se tais situações técnicas forem observadas vão "[...] possibilitar aos pesquisadores que se encontram distantes das áreas de pesquisa, fazerem observações através das imagens fotográficas".

Para que isto aconteça com suas características técnicas, é necessário que o responsável pelo registro da imagem tenha conhecimento básico sobre alguns pontos da linguagem fotográfica, isto é, o enquadramento, profundidade de campo, luz, dentre outros. Caso isso não ocorra, estará sujeito à perda de imagens; e seu trabalho não terá valor científico.

Em acordo com Campanholi $(2012$, p. 1),

Um dos desafios dos docentes neste século é a utilização e a apropriação de novas tecnologias em suas práticas docentes. Tecnologias essas que auxiliem o aluno a se tornar dono de suas próprias escolhas e decisões, tornando-o um aluno autônomo. A utilização da fotografia, como linguagem ou como documento, surge como espelho da realidade. Porém para utilizar a fotografia como uma nova ferramenta em sala de aula, no caso a fotografia é necessário que o docente tenha cuidado e atenção.

Contribuindo para nossas reflexões, ouvimos o depoimento de um professor de Matemática, que afirmou:

Uso fotografia, principalmente de cidades, para trabalhar as coordenadas e abscissas, [...]. Na matemática, usam-se fotografias de paisagens para se calcular ângulos, principalmente de casas, porque a sombra possibilita o uso do Teorema de Pitágoras, [...] razão, proporção e eixo de simetria. Além desses pode-se trabalhar com os insetos, pois 'possibilitam ao traçar o eixo de simetria', possibilidade do aluno perceber que o corpo do inseto apresenta lados iguais. Pode-se trabalhar 'as figuras geométricas', possibilitando-os guardarem 'triângulo', pois, através da imagem eles 'gravam melhor'. Uma outra possibilidade é a de 'visualização dos arcos de sustentação' hoje utilizados como 'parábola, numa função do segundo grau'. São observados ainda outros tipos de figuras, como a do 'tipo funil' (informação verbal). 
Este é outro ponto importante a ser observado, pois, a utilização da fotografia nos registros de espaços que possibilitem esses alunos visualizarem formas geométricas durante o ensino da matemática, por exemplo, vai contribuir para melhora na apreensão dos conteúdos.

Maciel, Rego e Carlos (2017, p. 351) discutem que:

[...] a visualização matemática tem grande importância para o desenvolvimento do pensamento matemático, uma vez que pode influenciar a construção de significados de conceitos matemáticos; ampliar a criatividade do aluno; e servir de ferramenta para o processo de ensino e aprendizagem de Matemática. Apesar de dificuldades apontadas por diversos pesquisadores no trato desse recurso, considerando aspectos cultural, cognitivo e sociológico, de maneira concisa, a visualização matemática seria uma forma de olhar e de pensar mais direcionado ao olhar em Matemática (Apud FLORES, 2010), através do qual o pensamento matemático se expressa.

Na disciplina de Artes, a professora realizou uma saída fotográfica que oportunizou aos alunos fazerem suas fotografias e discutirem na sala de aula aquelas imagens produzidas pelo grupo. O depoimento da referida professora em relação à atividade é o seguinte:

O aluno tem oportunidade de tirar a fotografia, ele sabe da importância, pois para ele ir confeccionar os materiais, fazendo a leitura do ambiente através da fotografia. No trabalho direcionado ao estudo, eles fotografaram a procissão, partindo daí para elaborarem um texto literário e, neste contexto trabalhar a redação. Foram e fotografaram todas as passagens da via-sacra, eles construíram um jornalzinho para o trabalho escrito, exibiram as imagens no data-show, oportunidade em que visualizavam e comentavam as imagens. A partir daí foi possível trabalharem a linguagem oral e passar para o texto, dentro da visão cristã. $\mathrm{Na}$ cidade de Jaru eles fotografaram a praça, saíram para fazer um passeio na cidade fotografando os pontos turísticos ou os mais importantes. Eles foram para a praça fotografaram a praça e com essas imagens partiram para explorar uma redação sobre a questão do meio ambiente. Eles observaram a existência de um chafariz (sic) que era utilizado para lavagem dos pés e jogavam lixos naquela localidade, sujando-a. Foi sugerido pelo grupo trabalharem a questão da educação e do meio ambiente. O local é um reduto de encontro social, onde as pessoas se reuniam para bater papo sobre suas vidas. A fotografia é muito importante (informação verbal).

Uma professora do Curso de Educação Física que ministra aulas de Ginástica e Dança na formação deste profissional, opina sobre a utilização 
da imagem fotográfica e o seu benefício no ensino da atividade física aos acadêmicos deste curso. Assim descreve:

Com a fotografia eu não faço isso, eu faço com filmagem, movimento. Eu não faço com fotografia porque não entendo e é muito difícil e eu não sei analisar. Eu olho, não consigo ver, só que quando eu congelo a imagem daquela filmagem fica ilegível, tremida e eu não vejo nada (informação verbal).

Diante da colocação da professora, observamos que a realização de cursos relacionados à fotografia e filmagem é necessária na formação continuada dos professores, pois eles vão contribuir para sua prática pedagógica.

Finalmente, trazemos exemplo da utilização da fotografia como recurso didático que foi realizado pelas alunas do curso de Pedagogia, na disciplina Ensino de Artes, onde efetuaram registros fotográficos dos espaços físicos de cursos da UNIR. A experiência foi assim relatada por uma acadêmica participante da pesquisa:

O meu envolvimento com a fotografia foi em decorrência de ter que efetuar um trabalho de conclusão de semestre, da Disciplina Fundamentos e Práticas do Ensino de Artes. Após várias discussões sobre a valorização do espaço universitário foi percebido a desvalorização de alguns cursos em relação a outros na universidade, assim resolvemos efetuar um registro fotográfico nesses espaços. Pois sempre se falavam destas diferenças, no entanto nunca eram mostradas, visualizadas pela comunidade acadêmica. Tais trabalhos nos oportunizaram a demonstrar através das imagens fotográficas a realidade que existe (sic) no Campus de Porto Velho. Esperamos que através desta Mostra os responsáveis fiquem sensibilizados e possam trazer melhorias (informação verbal).

Este último registro descrito propiciou, durante o momento em que a mostra ficou exposta no saguão da Biblioteca Central do campus da Unir, repercussão junto à comunidade acadêmica, fato este observado por nós, em que a maioria dos visitantes comentou "[...] nem imaginar que havia aquela diferença tão significativa entre os vários cursos da Universidade" (informação verbal). O trabalho foi de relevância, pois nos mostrou as 
diferentes percepções que os sujeitos constroem acerca das realidades que participam, neste caso, os diferentes espaços na Universidade.

O que nos leva à reflexão, em acordo com Oliveira et al. (2017, p. 2770) sobre o uso de imagens técnicas na Educação Ambiental de forma ampla, como "uma nova ética do olhar":

Considerando a Educação Ambiental de maneira ampla, que relaciona a experiência humana ao mundo natural de forma complexa e partindo da premissa básica de que o homem é um ser simbólico, é proposto, assim, a abertura para o desenvolvimento de atividades educacionais que utilizem a produção de imagens técnicas como forma de se trabalhar pedagogicamente questões relacionadas ao meio ambiente e sua relação com o mundo social, cultural e político. Pretende-se, a partir do destaque possibilitado pela produção crítica - e posterior fruição e reflexão - de imagens técnicas, ampliar as maneiras de ver e de compreender a sociedade, a natureza e o outro, numa nova ética do olhar.

Ignorar a existência do outro em uma época em que o "ter" é mais importante que o "ser" nos leva à necessidade de refletir e buscar um novo olhar para a realidade social e à utilização da fotografia para mediar este processo, como uma estratégia didática que nos auxilia nesta aproximação.

\section{CONCLUSÕES E RECOMENDAÇÕES}

Nesta pesquisa constatou-se que o uso da imagem fotográfica, utilizada como instrumento didático pedagógico nas aulas universitárias por professores e acadêmicos, tem contribuído como ferramenta metodológica, sendo um dos meios didáticos mais eficazes no ensino.

Os resultados demonstraram que os docentes, em sua maioria, utilizam as imagens fotográficas como recurso didático, sendo que estas possibilitam aos professores reflexão das atividades em sala de aula, contribuindo na sua formação e na formação dos seus alunos. Neste sentido, conclui-se que a utilização da imagem fotográfica contribui para o processo de ensino e aprendizagem na formação superior, auxiliando para uma prática pedagógica reflexiva. 
Recomendamos então a realização de cursos e oficinas de fotografia básica, aos acadêmicos, docentes e demais profissionais da educação, para subsidiarem e contribuírem em sua formação, pois, percebemos que estas atividades possibilitam o envolvimento da comunidade acadêmica do Ensino Superior e, oportuniza-os compreender a utilização da máquina fotográfica como meio de registro dos trabalhos acadêmicos realizados em ensino, pesquisa e extensão.

\section{REFERÊNCIAS}

ANDRADE, R. de. Fotografia e Antropologia: olhares fora - dentro. São Paulo: Estação Liberdade, 2002.

BARROS, A. M. de. et al. Quando a cegueira guia o olhar: notas sobre as práticas educativas inclusivas. Revista Benjamin Constant. Rio de Janeiro, v. 27, Artigo 1, p. 1-1 1, abril 2004. Disponível em:

http://www.ibc.gov.br/images/conteudo/revistas/benjamin_constant/2004/e dicao-27-abril/Nossos_Meios_RBC_RevAbr2004_Artigo_1.pdf. Acesso em $13 / 10 / 2020$.

CAMPANHOLI, J. A. M. O uso da fotografia na prática docente. Revista Pandora Brasil. n. 49, dezembro de 2012, p. 40-49. Disponível em: http://revistapandorabrasil.com/revista_pandora/docencia/julie.pdf. Acesso em 10/01/2021.

CARLOS, E. J. O texto em questão: re-significação conceitual e implicações pedagógicas. Revista Conceitos. João Pessoa, n. 8, p. 61-73, 2002. Disponível em:

https://www.researchgate.net/publication/316705314_Possibilidades_Pedago gicas_do_Uso_da_Imagem_Fotografica_no_Livro_Didatico_de_Matematica. Acesso em 07/01/2021.

DONDIS, D. A. Sintaxe da linguagem visual. Tradução de J. L. Camargo. 3. ed. São Paulo: Martins Fontes, 2007. (Coleção a).

MACIEL, A. de M. M.; REGO, R. G. do, CARLOS, E. J. Possibilidades Pedagógicas do Uso da Imagem Fotográfica no Livro Didático de Matemática. Revista Bolema. Rio Claro (SP), v. 31, n. 57, p. 344 - 364, abr. 2017.

MANSUR, D. A. O futuro da documentação fotográfica na era digital. Revista Pj:Br. n. 5, 10 sem. 2005. Disponível em: https://www.eca.usp.br/pjbr. Acesso em 10/01/2020. 
SILVA, I. F. de F.; SANTOS, F. K. S. dos; SILVA, L. L. da; CANEJO, V. P. A fotografia como recurso mediático no ensino de Geografia: a paisagem urbana em múltiplos olhares e convergências. XIII Encontro Nacional de Prática de Ensino de Geografia. Universidade Federal de Minas Gerais, 2017.

OLIVEIRA, M. F. S. de; OLIVEIRA, O. J. R. de; OLIVEIRA, C. F. S. de; OLIVEIRA, J. F. S. de. Fotografia e Educação Ambiental: o uso de imagens em práticas pedagógicas multidisciplinares. Seminário Gepráxis. Vitória da Conquista Bahia, v. 6, n. 6, p 2770-2782, 2017.

Recebido em: 19 de janeiro de 2021.

Aprovado em: 16 de março de 2021.

Publicado em: 31 de março de 2021. 